\title{
Endophytic Bacterial Effects on Seed as Enhancement in Germination with Mobilization of Reserves and Microbial Disinfection in Citrus Limon (L) by Biopriming Under Salinity Stress
}

\author{
Rathod Zalak R, Sarita Sharma and Saraf Meenu S* \\ Department of Microbiology and Biotechnology, University School of Sciences, India
}

Submission: October 4, 2021; Published: October 13, 2021

*Corresponding author: Saraf Meenu S, Department of Microbiology and Biotechnology, University School of Sciences, Gujarat University, Ahmedabad, Gujarat, India

\begin{abstract}
The main aim of this study was to analyze the mobilization of storage reserves during seed germination of Citrus limon by host plantendophytic bacteria interaction and to determine the contribution of endophytic bacteria in plant establishment. The seeds were inoculated with three different endophytic bacteria from Bacillus spp. which were isolated from the leaf of Citrus limon plant, and they were germinated in the dark. Fresh weight changes and early seedling growth were assessed, in all germinated and non-germinated seeds. To understand the mechanism promoting seed germination, the activities of extracellular enzymes of bacterial isolates were also analyzed by the plate assay method. The results showed that treatment with endophytic bacteria accelerated during the germination process. In summary, our current study showed that endophytic bacteria improved seed germination and post-germination seedling growth of Citrus limon plant inoculation with endophytic bacteria could promote storage reserve mobilization during or following germination; three bacterial isolates might have different action mechanisms on seed germination. The improved germination percentage and decreased germination period (GPD) using external agents can be exploited in conservation of this overexploited medicinally important plant.
\end{abstract}

Keywords: Citrus limon; Endophytic bacteria; Seed germination; Reserve mobilization

\section{Introduction}

The study of plant-endophytic bacteria interaction is quite significant for understanding the ecological and environmental impacts of this symbiotic association. Understanding the process better could provide researchers with new insights into biological control environmental remediation and plant stress resistance. Plant colonization by endophytic bacteria is also believed to help plants adapt better to the environment and then accelerate seedling emergence and plant establishment, especially in arid and semi-arid systems. There is an increasing body of evidence that suggests plant survival in arid ecosystems depends on specific bacterial communities that are capable of facilitating plant adaptation, improving plant functionalities and protecting plants from environmental stresses [1-4]. For example, interactions with endophytic bacteria help desert plants to establish themselves and grow on rocks without soil. Due to these beneficial effects, endophytic bacteria have been isolated from a variety of plant species grown in harsh environmental conditions, and these bacteria could be potential tools used for rehabilitation of degraded soils and vegetation. The bacterial communities in these plants are predominantly Proteobacteria and Firmicutes with a low abundance of Actinobacteria. The most studied endophytic plant growth-promoting bacteria were Bacillus and Pseudomonas strains, which were discovered through inoculation experiments. However, much less is known about the impacts of endophytic bacteria isolated from Ammodendron bifolium on plant growth and other plant performance parameters. A. bifolium (Pall.) Yakovl. is a perennial deciduous shrub distributed in the Takeermohuer Desert located in Northwestern Xinjiang and it is the only species of the Ammodendron genus in China. Although A. bifolium is an excellent sand-fixing plant, it is an endangered plant species due to anthropogenic activities [5]. Therefore, measures have been taken to protect it. Seed germination is a critical stage for plant survival and timely seedling establishment especially in stressful 
environments. Degradation and utilization of storage compounds during or following germination provide essential energy for early seedling growth prior to the development of autotrophy. Given the crucial performance of plant-associated microbiomes in soil restoration, seed germination and plant establishment in arid lands, endophytic bacteria from Citrus limon may also have potential value for studying their adaptation mechanisms in terms of plant microbe interaction. The three endophytic bacteria in this study were isolated from healthy tissues of wild Citrus limon plants, and they showed a promoting effect on germination and early seedling growth. Subsequently, we analyzed the physiological and biochemical processes underlying germination and early seedling growth in consortium by host plant-endophytic bacteria interaction and explored their adaptation strategies in arid and semi-arid desert areas as well as their potential for the restoration of degraded ecosystems. Seed dormancy is regarded as an intrinsic block that restricts the completion of germination of an intact viable seed under favorable conditions [6]. In the seeds of some plant species, the length of dormancy period is too long that affects the seed germination rate. Thus, low seed germination rate and overexploitation of some medicinal plants make them endangered. In the present study, seed germination rate of Citrus limon (L.) was improved by breaking seeds dormancy by treating with different chemicals as well as biological agents so as to conserve the plant from becoming extinct.

\section{Materials and Methods}

\section{Source of seeds}

Fresh Seeds of Citrus limon were used. They were taken from the fruit of Citrus limon plant from Nursery, Department of Horticulture Anand Agriculture University, (AAU). Citrus limon fruits were freshly harvested and taken in sterile zip lock polybag in ice box, transported into lab within $24 \mathrm{~h}$. Selections of good viable seeds were done by choosing the undamaged, unbroken proper and equal weight of seeds taken for pot culture experiment. Seeds were stored at room temperature.

\section{Seed sterilization}

Mature healthy seeds of Citrus limon were selected and wash the seeds with distilled water. Then the seeds were immersed in $3 \% \mathrm{H}_{2} \mathrm{O}_{2}$ for $20 \mathrm{~min}$. After 20 min decant the $\mathrm{H}_{2} \mathrm{O}_{2}$ and wash the seeds with sterile distilled water for 3 times. Decant all the distilled water and allow the seeds to dry in sterile clean surface. All work done in laminar air flow chamber.

\section{Germination rate}

Effect of endophytic bacteria on seed germination was studied by inoculating seeds of Citrus limon with individual bacteria as well as combination of all three bacteria. Twenty-five seeds were dipped for $24 \mathrm{hrs}$ in bacterial suspension, respectively. Seeds dipped in distilled water served as control. Both treated and untreated seeds have been incubated at $37^{\circ} \mathrm{C}$ in a moist chamber for 10 days. Till ten days observed the germinated seeds and measured. The test become achieved in triplicates and was repeated three times. The equation to calculate germination percent point out as beneath. The germination rate provides as measure of the time direction of seed germination [7].

$$
\% G P=\frac{\text { SeedsGer min ated }}{\text { Totalseed }} * 100
$$

\section{Bacterial strains and inoculant preparation}

Three endophytic bacteria used in this study (MSZLd, MSZLe and MSZPse) were isolated in our laboratory from different part of Citrus limon plant; root, stem, leaf, seed and juice etc and they stored at $-80^{\circ} \mathrm{C}$ in $20 \%(\mathrm{v} / \mathrm{v})$ glycerol. Total 27 Bacterial endophytes were isolated out of them three potent endophytic Bacillus spp. were selected for further studies. MSZLd, MSZLe both were isolated from leaf and MSZPse isolated from seed of Citrus limon plant. They identified as Bacillus subtilis (accession number MK592771), Bacillus Vallismortis (accession number MN533948), and Bacillus licheniformis (accession number MN160317) by 16S rRNA gene sequence analysis. To prepare inoculum, $1 \mathrm{ml}$ aliquots of a bacterial culture grown overnight were inoculated in $50 \mathrm{ml}$ nutrient broth with $150 \mathrm{rpm}$ at shaking condition. Subsequently, the accumulated biomass was harvested by centrifugation at $10000 \mathrm{~g}$ for $10 \mathrm{~min}$ at $4^{\circ} \mathrm{C}$, and the cell pellets were washed twice with phosphate buffered saline (PBS; $10 \mathrm{mM}$ sodium phosphate, $150 \mathrm{mM} \mathrm{NaCl}, \mathrm{pH} 7.0$ ) and finally suspended in PBS (approximately $10^{9}$ Colony Forming Units (CFU) $\mathrm{ml}^{-1}$ ).

\section{Seed bacterization}

Take sterile Petri plates and keep counted seeds in it. Spray broth on seeds for coating of bacterization of different endophytes and its combination of each other. Keep one sets for control. Then seeds allow to coat with After $24 \mathrm{~h}$ of seeds, allow them to germination in sterile clean room and spraying it with sterile distilled water regularly up to $10 \mathrm{~d}$. For control remains uninoculated [8].

\section{Statistical analysis}

Each treatment was repeated at least three times. The data are presented as the mean values \pm SE. Analysis of variance (ANOVA) followed by the Least Significance Difference test was carried out to compare treatments using SPSS 13.0 software. Differences were significant at $\mathrm{p}$ [8-10].

\section{Results and Discussion}

Seed germination and post-germination growth: Germination of Citrus limon seeds was tested after inoculation with three different endophytic isolates. From (Figure 1), it can be seen that seeds began to germinate after $3 \mathrm{~d}$ of imbibition, $5 \mathrm{~d}$ of imbibition and then germination increased obviously $10 \mathrm{~d}$ after imbibition. Isolate MSZPse significantly promoted seed germination at $3 \mathrm{~d}$ (18\%), $5 d(40 \%)$ and $5 d(88 \%)$, followed by MSZLe and MSZLd (14\% and $16 \%$ at $3 \mathrm{~d}$ and $32 \%$ and $38 \%$ at $5 \mathrm{~d}, 72 \%$ and $84 \%$ at $10 \mathrm{~d}$ respectively). In the control, the germination percentage 
was found to be $10 \%$ (at 3d), 28\% (at $5 \mathrm{~d}$ ) and $48 \%$ (at $10 \mathrm{~d}$ ). As shown in Figure 1, inoculation with the three isolates together as consortium made seeds further absorbed more water and then promoted the growth, which was increased by $24 \%, 50 \%$ and 96\% for MSZLd, MSZLe and MSZPse, respectively, after 10 days of treatment. It is well-known that plant growth-promoting bacteria are widely studied in agricultural crops but are rarely reported for wild plants, especially desert plants. It is proved that Citrus limon own plant endophytes increasing that itself for promotion in growth. Recently, several phosphate-solubilizing and diazotrophic bacteria from semi-arid and arid environments were selected for the study of plant growth promotion and were expected to be potential tools used for the reforestation and rehabilitation of degraded soil. Therefore, the three endophytic bacteria used in this study may also have potential roles for species conservation and their mechanisms for promoting plant growth may be diverse and deserve further study.

\% GP of Citrus limon seed

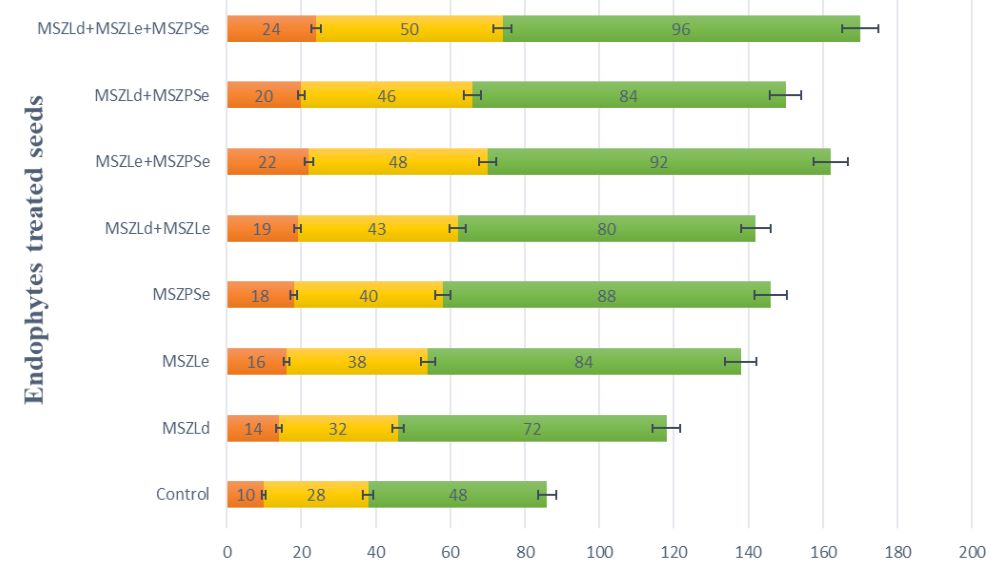

Days of seed germination

Ird $=$ - 5 thd $=10$ rth $d$

Figure 1: \% GP on Citrus limon seed.

\section{Conclusion}

Three endophytic bacteria from Citrus limon were shown to have a promotion effect on host plant seed germination and post-germination growth. At the same time, treatment with three endophytic isolates also promoted mobilization of storage reserves for providing essential energy to fuel growth. Therefore, Bacillus spp. as endophytic bacteria from Citrus limon may have potential value for reforestation in arid and semi-arid ecosystems.

\section{Conflict of Interest}

The authors have no conflict of interest in preparing of this article.

\section{Acknowledgement}

I am grateful to guide and Head of the Department of Microbiology and Biotechnology, Gujarat University for providing guidance and research facilities for conducting the research work.

\section{References}

1. Delshadi S, Ebrahimi M, Shirmohammadi E (2017) Influence of plant-growth-promoting bacteria on germination, growth and nutrients' uptake of Onobrychis sativa L. under drought stress. Journal of Plant Interactions 12(1): 200-208.
2. Hussain A, Jha DK (2018) Seed Germination Improvement of Caesalpinia bonducella (L.) Fleming by Biopriming.

3. KAPLAN R, Thavaranjit AC (2015) Promotion of vegetable seed germination by soil borne bacteria. Archives of Applied Science Research $7(8): 17-20$.

4. Lee Y, Lee YY, Kim YS, Balaraju K, Mok YS, et al. (2021) Enhancement of seed germination and microbial disinfection on ginseng by cold plasma treatment. Journal of Ginseng Research 45(4): 519-526.

5. Paredes Páliz KI, Pajuelo E, Doukkali B, Caviedes MÁ, Rodríguez Llorente ID, et al. (2016) Bacterial inoculants for enhanced seed germination of Spartina densiflora: Implications for restoration of metal polluted areas. Marine pollution bulletin 110(1): 396-400.

6. Raja K, Sivasubramaniam K, Anandham R (2017) Manipulation of seed germination and vigour by biopriming with liquid microbial cultures in paddy (Oryza sativa L.). Int J Curr Microbiol App Sci 6(10): 16121618.

7. Rathod Zalak R, Saraf Meenu S (2021) Effect of endophytes as phosphate solubilizing bacteria on Vigna radiata plant. Vidhya a journal of Gujarat University 1(1): 59-69.

8. Rathod Z (2016) Developing Plant Probiotic Bacteria based Bioformulation having PGPR Properties, Master of Philosophy thesis, School of Sciences of Gujarat University of India.

9. Rathod, Zalak R (2020) To Determine the Minimum Inhibitory Concentrations and Minimum Bactericidal Concentrations of the Effective Plants Extract and Endophytes of Citrus limon. Biotechnological Communication Special Issue (1): 210-215. 
10. Zhu YL, She XP, Wang JS, Lv HY (2017) Endophytic bacterial effects on seed germination and mobilization of reserves in Ammodendron biofolium. Pakistan Journal of Botany 49(5): 2029-2035. 